\title{
A NEW STANDARD COUNT ASSESSMENT FOR TESTING SPINNING QUALITY OF UPPER EGYPT COTTONS
}

\author{
EL-SAYED, M. A. M.
}

Cotton Research Institute. Agricultural Research Center, Giza, Egypt

(Manuscript received 12 October 2006)

(Manuscript received 12 October 2006)
Thstract
The present study was carried out on the Upper Egypt Long-
Staple cottons to assess an appropriate new standard count for
comparing the strength level of Upper Egypt cottons tested in the
breeding, maintenance and regional evaluation and other research
programs.
Two Egyptian commercial cotton varieties belonging to Upper
Egypt Long-Staple category namely; Giza 80 and Giza 90 were used
in this study. All cotton samples were processed into three yarn
structures; two nominal counts 40 s with 3.6 and 4.0 twist
multipliers, and a third nominal 60 s with 3.6 TM.
The results demonstrated that the proposed standard count
40s with 4.0 twist multiplier being the least in yarn count, lea
strength variation, and number of end breakages and gave the
optimum quality. Furthermore, it reduces the time per test.
Consequently, it is expected the order of ranking of different strains
which could affect selection is changed and led to less rejected
samples. The suggested count correction factor to be used is 1.2
units to be added if the yarn is finer and subtracted if it is coarser
than the nominal count, from the lea strength.

\section{INTRODUCTION}

In the Spinning Research Section, Cotton Research Institute "CRI", yarn strength of all the tested cotton breeding, maintenance, and regional evaluation programs are tested only for the value of lea count strength product "lea product" of 60 s carded yarns with twist multiplier 3.6 since it was defined by Hancock (1937) as a happy standard count for comparing the yarn strength levels of the Egyptian cottons.

In 1987, Syiam et. al. studied the potentiality of using the nominal 40 s carded count as an additional standard count for comparing the strength level of Upper Egypt cottons, aiming at enabling the Egyptian cotton breeder to combine yield and quality among such cottons under two levels of standard counts (60s and $40 \mathrm{~s}$ ). They concluded that, decreasing yarn count caused decreasing yarn strength variation, yarn count variation, range of actual count, and increased yarn strength with different degrees with different cottons. Consequently, the order of ranking different strains which could affect selection had been changed and led to less rejected samples.

The CRI did not apply the results of this study, may be because two standard counts will increase the time and costs of testing, and insufficient raw cotton samples 
for two standard counts since the cotton breeder's work demands a great deal of selection, especially at early stage of development which give small quantities of cotton lint.

The present study was carried out on the Upper Egypt Long-Staple cottons, to assess appropriate 40 s yarn count as a new standard count for comparing the strength level of Upper Egypt cottons tested in the breeding, maintenance and regional evaluation programs supported by the number of end breakage per 192 spindle/hour.

\section{MATERIALS AND METHODS}

Two Egyptian commercial cotton varieties belonging to the Upper Egypt LongStaple category namely; Giza 80 and Giza 90 were used in this study. The HVI Spectrum raw fiber data are presented in Table 1.

Four groups containing 540 leas from each treatment were tested on GoodBrand Lea Tester to determine lea count strength product "LCSP". The broken leas were weighed by a Sauter Alfered Balance to estimate its actual count. The Confidence limit (C.L.) and Degree of precision (E) and coefficient of variation were used to determine the actual count and lea strength variation within each cotton sample. The actual count and the count variation were estimated within each cotton sample. Fiber and yarn properties were determined under ASTM (1991) standard at the Cotton Technology Research Laboratories, Cotton Research Institute, Giza, Egypt.

Table 1. HVI Spectrum fiber data.

\begin{tabular}{|c|c|c|c|c|c|c|}
\hline $\begin{array}{c}\text { Cotton } \\
\text { variety }\end{array}$ & $\begin{array}{c}\text { UHM. } \\
(\mathrm{mm})\end{array}$ & $\begin{array}{c}\text { U.I. } \\
(\%)\end{array}$ & $\begin{array}{c}\text { Short Fiber } \\
\text { Index }\end{array}$ & $\begin{array}{c}\text { Strength } \\
(\mathrm{g} / \text { tex })\end{array}$ & $\begin{array}{c}\text { Elongation } \\
(\%)\end{array}$ & Micronaire \\
\hline Giza 80 & 31.2 & 85.2 & 8.9 & 38.2 & 7.9 & 4.3 \\
\hline Giza 90 & 30.5 & 85.0 & 9.8 & 35.4 & 7.6 & 4.3 \\
\hline
\end{tabular}

All samples were processed into three yarn structures; two nominal counts 40s with 3.6 and 4.0 twist multipliers (TM), and a third nominal 60 s with 3.6 TM according to Hancock (1945) as follow:

Grouping and sampling. At most 12 samples of Upper Egypt cotton are assembled in a group, representative samples of 60 grams should be drawn out in such way.

Carding: Carding machines at old experimental spinning mill are modified to card two samples at same time, so a sample of 60 grams is processed through a second card to provide a sliver weighing approximately 48 grams. 
Drawing: two processes of drawing are used for the lap of each sample delivered from the sliver lap. Both first and second drawing sliver being of normal weight of 0.26 hank.

Slubber, intermediate and rover speed frames: At most 12 samples of a group previously assembled are treated simultaneously. There are two doffings at each of the three speed frames. The group (12 samples) does not arrive at the same mean hank, although they are given identical treatments and three frames are fixed to a standard setting. The stands delivered from these three frames being of average normal weight $1.30,3.25$ and 8.12 hanks respectively. Each of these three speed frames are intended to draft out the fibers into much smaller strand, inserting enough twist to give adequate strength for further handling and winds the strand of each sample onto two bobbins.

Spinning: the roving group is ${ }^{*}$ processed through the ring frame after adjustment of the correct yarn count ( $60 \mathrm{~s}$ and $40 \mathrm{~s}$ in this study). 18 leas of both yarn counts are produced per sample send for testing on four ring bobbins, called four doffing that means the yarns of each sample are winded equally onto four bobbins all bearing the same number of the sample.

For the spinning performance evaluation, the total number of ends down per 192 spindle/hour for each yarn number was plotted against yarn count. The intersection of this trend line with an arbitrary number of end breakages (16 in this investigation) represents the so-called "spinning limit".

\section{RESULTS AND DISCUSSION}

\section{Fiber properties}

It could be expected that the range of each fiber property is narrow since all the cotton varieties belong to the same category.

The two varieties of Upper Egypt, Giza 80 and Giza 90, are of high short fiber index and low fiber strength in comparison with Long Staple cottons grown in Delta. Giza 80 is of a somewhat higher comprehensive quality level than Giza 90, the latter being the variety of lowest quality among Egyptian cottons.

If the Egyptian Long-Staple cotton varieties are to be arranged in a descending manner according to the comprehensive evaluation of quality, Long Staple Delta cottons come first and Upper Egypt Long Staple cottons come later.

Reasons for choosing 40's as a new standard count for testing spinning quality of Upper Egypt cottons

40 's carded count is a reasonable compromise, tending towards the lower end of the Egyptian range; 40's count could be adopted without the introduction of bias. 
According to Hancock (1937), who established the small samples spinning technique in CRI, reported that, when tests are required on cottons of low grade or on samples which are known to be weak, it might be necessary to lower the count to 40 's. Also, the end uses of this category mainly, at local textile industry, for the production of coarse and medium yarns, commonly, spun at 40 s count.

\section{Lea count strength product}

The experimental spinning mill, which was expanded in 1965, runs according to a system using very small samples of lint (60 grams) with manual preparations, partly to cope with smaller quantities of cotton available from the families in breeding plots, and also for the sake of testing speed. Therefore when testing the hybrids and cotton strains, this system can't give very accurate spinning potential of the standard carded count used at the CRI, (60s with 3.6 TM) which is very fine for Upper Egypt Long-Stable cottons.

In general, lea count strength product increases with increase in the number of fibers in yarn cross-section, from $60 \mathrm{~s}$ to $40 \mathrm{~s}$. Also, with increasing twist multiplier from 3.6 to 4.0 at the same count (40s) caused increased LCSP for both Giza 80 and Giza 90 from 170 to 200 units meaning that these cottons are below the optimum twist needed to reach maximum strength. Changing yarn count from $60 \mathrm{~s}$ with $3.6 \mathrm{TM}$ to $40 \mathrm{~s}$ with $3.6 \mathrm{TM}$ caused an average increase in strength of 160 units, within a range of 120 to 200 units for both Giza 80 and Giza 90 respectively, Tables 2 and 3 and Figure 1.

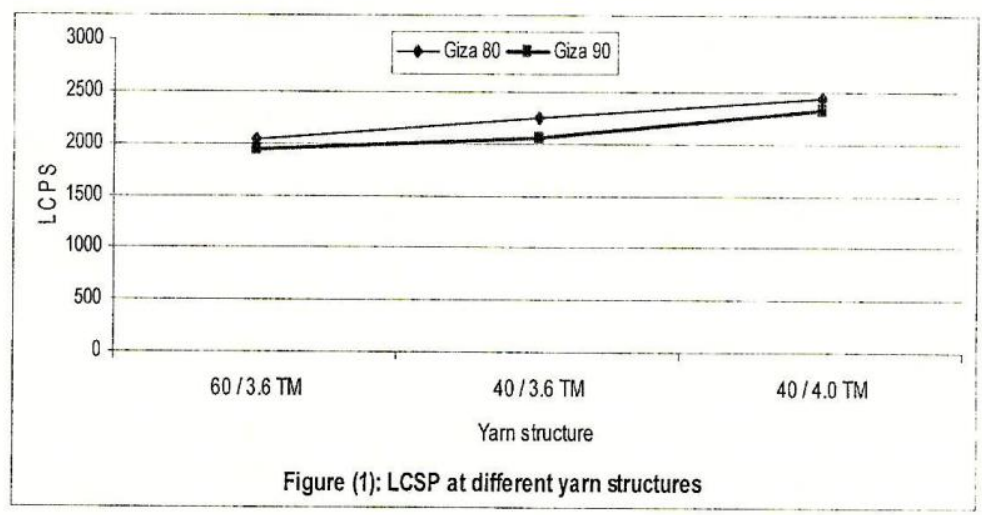


Table 2. Yarn testing results of Giza 80 spun at different yarn structures

\begin{tabular}{|l|c|c|c|c|c|c|c|c|c|}
\hline & \multicolumn{3}{|c|}{60 s with 3.6 TM } & \multicolumn{3}{c|}{40 s with 3.6 TM } & \multicolumn{3}{c|}{40 s with 4.0 TM } \\
\hline & $\begin{array}{c}\text { Lea } \\
\text { strength }\end{array}$ & $\begin{array}{c}\text { Actual } \\
\text { count }\end{array}$ & LCSP & $\begin{array}{c}\text { Lea } \\
\text { strength }\end{array}$ & $\begin{array}{c}\text { Actual } \\
\text { count }\end{array}$ & LCSP & $\begin{array}{c}\text { Lea } \\
\text { strength }\end{array}$ & $\begin{array}{c}\text { Actual } \\
\text { count }\end{array}$ & LCSP \\
\hline $\begin{array}{l}\text { Average } \\
\text { (540 Leas) }\end{array}$ & 35.55 & 57.58 & 2038.57 & 57.6 & 38.48 & 2240.6 & 60.88 & 41.34 & 2440 \\
\hline $\begin{array}{l}\text { Confidence } \\
\text { Limit }\end{array}$ & 1.39 & 1.15 & 55.07 & 1.89 & 0.57 & 41.36 & 1.24 & 0.39 & 37.26 \\
\hline $\begin{array}{l}\text { Degree of } \\
\text { precision }\end{array}$ & 3.91 & 2.00 & 2.70 & 3.06 & 1.48 & 1.79 & 2.04 & 0.95 & 1.49 \\
\hline C.V.\% & 10.56 & 5.70 & 7.41 & 10.38 & 5.24 & 6.33 & 7.30 & 3.24 & 5.04 \\
\hline $\begin{array}{l}\text { No. of ends } \\
\text { down }\end{array}$ & \multicolumn{7}{|c|}{40} & & \multicolumn{7}{|c|}{22} & & & 8 & \\
\hline
\end{tabular}

Table 3. Yarn testing results of Giza 80 spun at different yarn structures

\begin{tabular}{|c|c|c|c|c|c|c|c|c|c|}
\hline & \multicolumn{3}{|c|}{60 s with $3.6 \mathrm{TM}$} & \multicolumn{3}{|c|}{40 s with $3.6 \mathrm{TM}$} & \multicolumn{3}{|c|}{$40 \mathrm{~s}$ with $4.0 \mathrm{TM}$} \\
\hline & $\begin{array}{c}\text { Lea } \\
\text { strength }\end{array}$ & $\begin{array}{l}\text { Actual } \\
\text { count }\end{array}$ & LCSP & $\begin{array}{c}\text { Lea } \\
\text { strength }\end{array}$ & $\begin{array}{l}\text { Actual } \\
\text { count }\end{array}$ & LCSP & $\begin{array}{c}\text { Lea } \\
\text { strength }\end{array}$ & $\begin{array}{c}\text { Actual } \\
\text { count }\end{array}$ & LCSP \\
\hline $\begin{array}{l}\text { Average } \\
\text { ( } 540 \text { Leas) }\end{array}$ & 37.31 & 54.79 & 2033.45 & 55.63 & 39.04 & 2148.54 & 58.66 & 39.67 & 2320 \\
\hline $\begin{array}{l}\text { Confidence } \\
\text { Limit }\end{array}$ & 1.83 & 0.71 & 42.31 & 1.09 & 0.94 & 38.2 & 1.22 & 0.53 & 36.42 \\
\hline $\begin{array}{l}\text { Degree of } \\
\text { precision }\end{array}$ & 3.28 & 1.83 & 2.06 & 2.93 & 1.729 & 1.97 & 2.08 & 1.34 & 1.56 \\
\hline c.v.\% & 10.03 & 5.91 & 6.75 & 11.5 & 6.49 & 7.22 & 7.44 & 4.09 & 5.10 \\
\hline $\begin{array}{l}\text { No. of } \\
\text { ends down }\end{array}$ & \multicolumn{3}{|c|}{48} & \multicolumn{3}{|c|}{21} & \multicolumn{3}{|c|}{8} \\
\hline
\end{tabular}

\section{Coefficient of variation in lea strength and actual yarn count}

At the ring frame all the twelve samples of a group are spun simultaneously, occupying 12 spindles; twelve doffings are made, each sample moving along to the next spindle after every doffing, so that after twelve doffings every sample has been on every spindle, such procedure eliminates the spindle error and variation withinbobbin inside a group.

According to Tables 2 and 3, the statistical analysis showed a decrease of draft ratio (i.e. increase the number of fiber in yarn cross-section) would mean decrease in actual yarn count coefficient of variation from 60 s to $40 \mathrm{~s}$. If the count C.V. $\%$ are 3.24 and 4.09 in 40 s / 4.0 TM, then it could be shown that the count C.V. \% will be higher to 5.70 and $5.91 \%$ in 60 s / 3.6 TM for both Giza 80 and Giza 90, respectively. Moreover, there is a slight trend for 40s/4.0 TM count to show lower C.V. $\%$ than the respective 40s/3.6 TM (5.24 and 6.49\% for both Giza 80 and Giza 90)

However, lea strength C.V. \% within each cotton variety exhibited a decrease from $10.56,10.03$ on $60 \mathrm{~s} / 3.6 \mathrm{TM}$ to $7.30,7.44$ at $40 \mathrm{~s} / 4.0 \mathrm{TM}$ for both Giza 80 and Giza 90 , respectively. 
It could be noticed that the 60 s carded yarns had higher mean values for the actual count C.V.\% than the observed yarns spun into the 40 s meaning that coarser yarns were known to be relatively more uniform in size than the finer ones. These results are agreement with Ratnam et. al. (1972) who reported that the average count C.V. \% in 70 mills based on 300 tests is $4.7 \%$ in fine counts (60s and finer and $4.1 \%$ in coarse count (36s and coarser).

According to the Confidence limit and Degree of precision as shown in the equation: Confidence limit (0.95 significant level $=1.96 \times$ Standard Deviation $/ \sqrt{ } \mathbf{n}$

Degree of precision = confidence limit/ average $\mathrm{X} 100$

It could be stated that the degree of precision of the 60s with $3.6 \mathrm{TM}$ for lea strength, actual count and LSCP decreased markedly when yarn became coarser; $40 \mathrm{~s}$ with 3.6 $\mathrm{TM}$ and $40 \mathrm{~s}$ with $4.0 \mathrm{TM}$. The degree of precision of $40 \mathrm{~s}$ with $4.0 \mathrm{TM}$ recorded the lowest value (1.49 and $1.56 \%$ ) than the $60 \mathrm{~s}$ with $3.6 \mathrm{TM}$ (3.91 and 3.28\%) and $40 \mathrm{~s}$ with $3.6 \mathrm{TM}$ which recorded 1.79and $1.97 \%$ for Giza 80 and Giza 90, respectively. The same trend was noticed for the confidence limit for the characters studied.

\section{Twist multiplier}

The optimum twist multiplier used at the proposed yarn count was 4.0, and it is near to that commonly quoted as the twist factor for maximum strength for Upper Egypt type of cotton in single yarns especially which used at the weaving. 4.0 TM appears to be entirely satisfactory for the purpose for which it is intended.

The twist multiplier at which test yarns are spun has some influence on lea count strength product as a whole; as noted by Abdel-Salam (1972), who reported that the optimum twist multiplier for the short and coarse variety was greater than that for the longer and finer variety.

\section{Time per test}

When the technique was applied at 60s with $3.6 \mathrm{TM}$, the time of spinning work was 4 groups per 6 hours. But, with using the proposed new standard count $40 \mathrm{~s}$ with $4.0 \mathrm{TM}$, the time of spinning was 4 groups per 4 hours, meaning that the proposed yarn count reduced the time of testing by about one third which would shorten the working season.

\section{Count correction}

Under the conditions of spinning test, further correction is necessary, because fairly large count variations are liable to arise. When second draw-frame slivers of equal hank but from different cottons passed through slubber, intermediate, roving and spinning even though they are given simultaneous identical treatment, they do not all arrive at the same count. Consequently, lea count strength product has to be corrected to the nominal count in order to be comparable. In this respect, Aboul-Fadl 
et. al. (1987) studied the correction factor for the standard counts for the proposed standard count 40 s carded count; they suggested the correction factor to be used is 1.2 added to the lea strength if finer and subtracted if coarser.

End breakage

The spinning limit of cotton, normally judged by its performance during spinning in terms of end-breakage rate, is of major importance to the textile industry, because of its significant effects on time of testing, quality and employee morale.

It should be recognized that in this test used small samples were used. To obtain a sufficient number of end breaks larger samples should be used. As a result, findings of this study should be accepted with appropriate reservations.

Tables 2 and 3 showed the number of end breakage data obtained during spinning of the two cottons into the various yarn counts. In Figure 2 the number of end breakage frequencies is plotted against yarn count. Naturally, the number of end breakage increased as counts became finer.

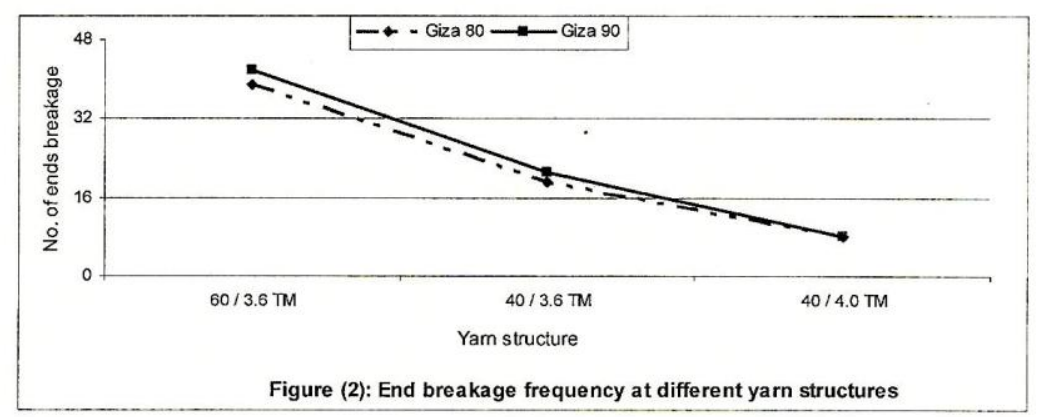

In cases of 40 yarn count, found distinct differences were lowed in the way the low and high twist yarns broke down. The low twist (3.6 TM) yarns were seen to have a predominant increase in number of end breaks (22 and 21), while the high twist (4.0 TM) yarns showed a decrease in number of end breaks (8) for both Giza 80 and Giza 90, respectively. This result is basically due to the higher yarn strength for the higher twist and the high amount of short fiber index as shown in Table 1 . This finding is supported by Abdel-Salam (1995) who stated that a higher amount of short fibers results in higher rates of ends down, mainly because of slippage and increased yarn cross-sectional irregularity. On the other hand, lower fiber length uniformity reduces the spinning limit through its inverse effect on yarn cross-sectional irregularity. 


\section{REFERENCES}

1. Abdel-Salam, M. E. 1972. The relationship between yarn fineness and twist multiplier and yarn physical properties of Giza 45 and Ashmouni. Agric. Res. Rev. Egypt, 50: 125-139.

2. Abdel-Salam, M. E. 1995. Fiber characteristics in relation to processing and yarn quality. ICAC.

3. Aboul-Fadl, S.M., M.M. Syiam, A.M. Ismail and M.A. Abdel-Mohsen. 1987. Yarn count variations and setting correction factors for new standard counts used at "cotton technology research laboratory, Giza". Agric. Res. Rev., 65 (4): 725-737.

4. ASTM. 1991. American Society for Testing and Materials. Standards of textile testing and materials. Philadelphia, Pa.

5. Hancock, H. A. 1937. A spinning procedure for cotton samples. J. Textile Inst. Vol. 28: 161-176.

6. Hancock, H. A., 1945. Uses and accuracy of cotton spinning tests on 60-Gram samples. J. Tex. Inst. Vol. XXXVI. 10-18.

7. Ratnam, T. V., K. ranganathan, and K. Govindarajulu. 1972. Lea count variation in yarn. Text. Res. J. 42. (5): 257-260.

8. Syiam, M. M., S. M. aboul-Fadi, A. S. I. Marzouk and E. M.S. Sawires.1987. Anew standard yarn count for testing spinning quality parameters of Upper Egypt Long Staple cottons. Agric. Res. Rev., 65 (4): 711-723. 


\section{تأكيا اختيار نمرة قياسية جديدة لاختبار جودة الغزل لأقطان الوجه القبلى}

محمد عبد الترحمن محمد السبيد

$$
\text { معثل بحوث القطن - مركز البحوث الزراعية - الجبيزة }
$$

أجريت هذه الدر أسة بهوف اختياز نمرة قياسية جديدة لمقارنة مسنوى متانة الخيوط المنزولة

لبر امج التزبية و المحافظة و الثقييم الإقليمي التى تتبع مجموعة أقطان الوجه القبلى بمعهد بحوث القطن أستخدم لهذه الدراسة صنفان من القطن هما جيزة .^ وجيزة .9 يتبعان مجموعة أقطان

الوجه القبلى ، كل العينات تم غزلها على ثلاث نمر غزلية هى نمرة . ؛ بمعامل برم r,r ونمرة

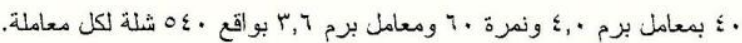

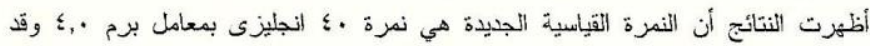

اختيرت بناه على اختبار درجة الدقة ، كما أن النمرة الغزلية المقترحة أقل معامل اختلاف لكل من النمرة ومعامل الببرم ومثانة الشلة و كذلك معدل قطوع مناسب وذات مستوى جودة مقبول. علاوة على ذلك، فإن اختيار النمرة القياسية الجديدة يقلل زمن التشغيل التلزم. بالتالى، من المتوقع أن انخفاض النمرة الغزلية من · ج اللى .ع انجليزى يؤدى الى خفض عدد العيناث المرفوضة من تلك الثبر امج تحت الدراسة. معامل التصحيح المقنرح هو ب, 1, وحدة بضاف الى الثقل القاطع للثلة إذا كانت النمرة الغزلية الفعلية أعلى من النمرة الإسمية ويطرح إذا كانت النمرة الغزلية الفعلية أقل من 